\title{
Making a tooth: growth factors, transcription factors, and stem cells
}

\author{
Yan Ding ZHANG ${ }^{1,2}$, Zhi CHEN ${ }^{1}$, Yi Qiang $\mathrm{SONG}^{3}$, Chao $\mathrm{LIU}^{2}$, Yi Ping CHEN ${ }^{2,3, *}$ \\ ${ }^{1}$ College of Stomatology, Wuhan University, Wuhan 430072, China \\ ${ }^{2}$ College of Bioengineering, Fujian Normal University, Fuzhou 350007, China \\ ${ }^{3}$ Division of Developmental Biology, Department of Cell and Molecular Biology, Tulane University, New Orleans, LA 70118, \\ USA
}

\begin{abstract}
Mammalian tooth development is largely dependent on sequential and reciprocal epithelial-mesenchymal interactions. These processes involve a series of inductive and permissive interactions that result in the determination, differentiation, and organization of odontogenic tissues. Multiple signaling molecules, including BMPs, FGFs, Shh, and Wnt proteins, have been implicated in mediating these tissue interactions. Transcription factors participate in epithelial-mesenchymal interactions via linking the signaling loops between tissue layers by responding to inductive signals and regulating the expression of other signaling molecules. Adult stem cells are highly plastic and multipotent. These cells including dental pulp stem cells and bone marrow stromal cells could be reprogrammed into odontogenic fate and participated in tooth formation. Recent progress in the studies of molecular basis of tooth development, adult stem cell biology, and regeneration will provide fundamental knowledge for the realization of human tooth regeneration in the near future.
\end{abstract}

Keywords: tooth development, transcription factor, growth factor, stem cells, regeneration.

\section{INTRODUCTION}

Vertebrate organ development, from the initiation to terminal differentiation, depends upon inductive interactions typically between epithelium and adjacent mesenchyme $[1,2]$. The inductive interactions consist of two main components: a tissue capable of producing the inducing stimulus and a tissue capable of receiving and responding to it. At the molecular level, these interactions involve complex signaling networks composed of various signaling molecules, their receptors, and the transcription control systems. It has been clear that embryonic inductions via cell and tissue interactions are mediated by diffusible protein signaling molecules known as growth factors. Prominent among these are Bone Morphogenetic Proteins (BMPs), Fibroblast Growth Factors (FGFs), Wnt, and Hedgehog (Hh) families. These growth factors function synergistically and/or antagonistically to organize and pattern tissues and organs during embryonic development. Growth factor functions through binding

*Correspondence: Yi Ping CHEN

Tel: +504-865-5587; Fax: +504-865-6785;

E-mail: ychen@tulane.edu to its specific cell membrane-bound receptor that triggers intracellular signal pathway, leading to signal transduction into the nucleus where latent transcription factors are activated, and eventually causing change of gene expression. The expression of many transcription factors during development of many organs has been revealed. The overlapping expression patterns of transcription factors and growth factors in developing organs suggest a relationship between these two classes of gene products in inductive interaction. It was proposed that transcription factors in a tissue layer activate the expression of growth factors in response to the signaling of growth factors produced from the adjacent tissue, forming a signaling network that regulates organogenesis [3].

Mammalian tooth development shares many similarities with other embryonic organs. The mouse tooth has long served as a model organ for studying fundamental questions of developmental biology such as epithelial-mesenchymal inductive interactions, differentiation, and pattern formation [4]. This is mainly due to the ease with which it can be accessed, manipulated, and cultured in vitro, and be transplanted to ectopic sites where it can develop and differentiate into a recognizable tooth organ.

Clinically, tooth allotransplantation, autotransplantation, 


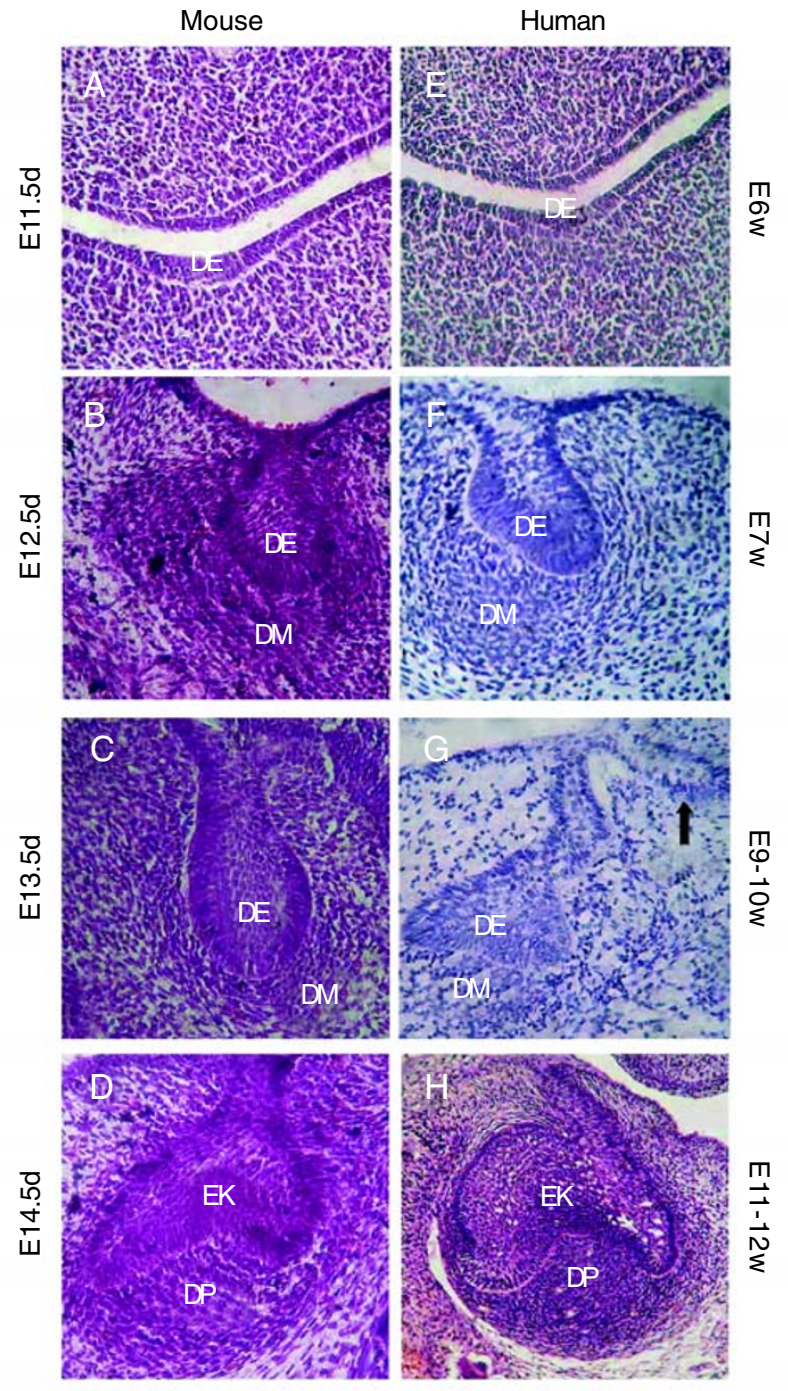

Fig. 1 The early stages of molar tooth development in the mouse and human embryos. (A-D) the mouse molar tooth germ at the lamina stage (A), the early bud stage (B), the late bud stage (C), and the cap stage (D). (E-H) the human molar tooth germ at the lamina stage $(\mathbf{E})$, the early bud stage $(\mathbf{F})$, the late bud stage $(\mathbf{G})$, and the cap stage $(\mathbf{H})$. Note the presence of the secondary tooth germ (STG) in $(\mathbf{G})$. Abbreviation: DE, dental epithelium; DM, dental mesenchyme; DP, dental papilla; EK, enamel knot; STG, secondary tooth germ.

and dental implants have been traditionally used as prosthetic procedures for tooth replacement for many years. Although missing or damaged teeth are not life-threatening, it apparently affects the quality of human's daily life. Stem cell-based tissue engineering approaches to generate organ and tissue for the clinical application appear very promising [5]. Recent studies have greatly prompted the potential application of stem cells in tooth regeneration.

\section{Embryology of mammalian tooth development}

Sequential and reciprocal interactions between the cranial neural crest-derived mesenchymal cells and the stomadial epithelium regulate tooth morphogenesis and differentiation [6]. In mice, the dental mesenchyme is attributed by neural crest cells derived from the midbrain and hindbrain region around embryonic day 8.5 (E8.5) [7-10]. The determination of tooth forming sites and tooth type occurs around embryonic day 10.5 (E10.5) [11-13]. At E11.5, the first morphological sign of molar tooth development appears as a local thickening of the dental epithelium. During this process, the presumptive dental epithelial cells elongate along their apical-basal axis, change cell shape from cuboidal to columnar, assume an apical-basal polarity (polarization) and form a dental placode (Fig. 1A). At the E12.5 and E13.5 bud stage, the thickened dental epithelium proliferates and invaginates into the subjacent mesenchyme to form the epithelial tooth bud around which the mesenchymal cells condense (Fig. 1B, 1C). During these stages, the basal layer cells of the epithelial bud maintain columnar shape. At the E14.5 cap stage, the epithelial component undergoes specific folding, which is accompanied by the formation of the enamel knot, a transient cluster of non-dividing epithelial cells (Fig. 1D). A unique set of signaling molecules, including Shh, BMP2, BMP4, BMP7, FGF4, and FGF9, are expressed in the enamel knot. The enamel knot is therefore considered to be a signaling center to control the patterning of the tooth cusps [14]. During the subsequent bell stage, the epithelially derived ameloblasts and mesenchymally derived odontoblasts differentiate. In addition, the mesenchymal cells differentiate into alveolar bone that forms the sockets for the teeth [15]. The human tooth development shares great similarity to that of the mouse in the early process, including the lamina, the bud, and the cap stages (Fig. 1E, 1F, 1G, 1H). At the sixth week of human embryonic development, the cuboidal epithelial cells in the site of presumptive dentition elongate into columnar epithelial cells, and form a thickened horseshoe shaped epithelial band, namely the dental laminar, around upper and lower jaws (Fig. 1E). At the seventh week, successive but uneven proliferation in the thickened dental laminar leads to formation of 10 dental epithelial buds at intervals that will develop into the presumptive enamel organs of the primary teeth (decidous teeth) (Fig. $1 F)$. From the eighth to the tenth week, the dental epithelial bud invaginates further into the subjacent dental mesenchyme, forming a tooth germ at the late bud stage, (Fig. 1G). Meanwhile, small diverticulums spring from the dental epithelial buds on the superficial side, and become the secondary tooth buds (permanent tooth buds) (Fig. $1 \mathrm{G})$. These secondary tooth germs pause at the bell stage and resume until the primary teeth are replaced. At the 


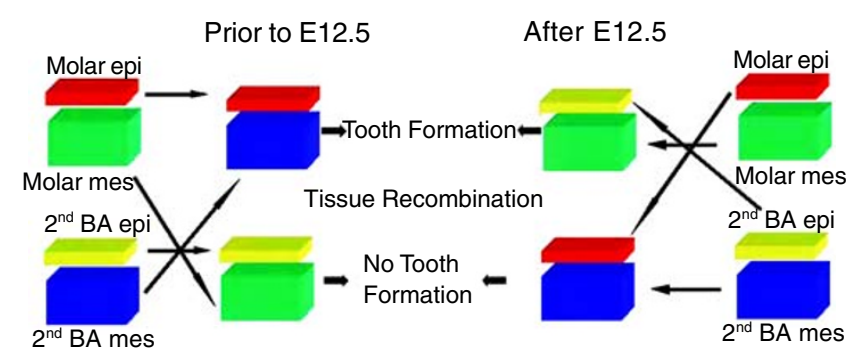

Fig. 2 The odontogenic potential shifts from dental epithelium to mesenchyme during early mouse tooth development. The molar epithelium prior to E12.5 possesses the odontogenic potential and is capable of inducing tooth formation when recombined with nondental mesenchyme. After E12.5, the odontogenic potential shifts to the molar mesenchyme which is able to instruct tooth formation when recombined with non-dental epithelium. Abbreviation: $2^{\text {nd }} B A$, secondary branchial arch; epi, epithelium; mes, mesenchyme.

tenth week, tooth germs assume cap-like structure (Fig. $1 \mathrm{H})$.

The odontogenic potential represents an instructive induction capability of a tissue to induce gene expression in an adjacent tissue and to initiate tooth development. On the other hand, the odontogenic competence represents the capability of a tissue to respond to odontogenic signals and to support tooth formation. Tissue recombination experiments between isolated mouse dental epithelial and mesenchymal tissues have demonstrated that during early mouse molar tooth development, the odontogenic potential initially resides in the dental epithelium, and then shifts to the mesenchyme $[16,17]$. At the pre-bud stages of development (before and at E11.5) the presumptive dental epithelium possesses the potential, capable of inducing tooth formation when confronted with non-dental mesenchyme (Fig. 2). However, only the cranial neural crest derived mesenchyme is odontogenic competent. Teeth failed to form when dental epithelium was recombined with nonneural crest derived mesenchyme, such as limb mesenchyme [17]. In contrast, at the early bud stage (E12.5), the odontogenic potential has switched to the mesenchyme (Fig. 2), which becomes able to instruct non-dental epithelium to form tooth-specific structures [16-18]. The odontogenic potential then remains in the dental papilla that also controls tooth shape till birth [18-20].

\section{GROWTH FACTORS MEDIATE INDUCTIVE INTERACTIONS DURING ODONTOGENESIS}

Classic studies have demonstrated the importance of cross-talk between dental epithelium and mesenchyme during tooth development. The isolated component of embryonic mouse tooth germs, either epithelium or mesenchyme fails to undergo cytodifferentiation, and the epithelium dies when grown in isolation [21]. However, physical separation by Millipore filter between epithelium and mesenchyme allows enamel organ and papilla differentiation with the deposition of matrix. These studies indicate that the cross-talk between these two tissue layers is required for their normal differentiation or survival, and the communications are mediated by diffusible signaling molecules. It is clear now that these diffusible molecules are growth factors.

\section{Bmps}

Recent studies have implicated BMPs in mammalian tooth development from the very beginning. Although the expression of several Bmp genes in tooth development has been reported in many studies, BMP4 is the one suggested to play a central role during tooth morphogenesis [14]. Around E10, when the determination of the tooth forming site and tooth type occurs, the antagonistic effects of epithelially expressed $B m p 4$ and $F g f 8$ restrict $P a x 9$ expression to the presumptive dental mesenchyme $[11,13]$ and the expression of Pitx 2 to the presumptive dental epithelium [22]. The tooth type is meanwhile determined. The expression domain of Barx1, a homeodomain transcription factor necessary for the molar tooth type specification, is restricted to the molar anlage by BMP4 that is expressed in the distal region of mandible [12, 23]. On the other hand, this distally expressed BMP4 induces Islet1 expression in the future incisor mesenchyme [24]. Subsequently, multiple genes encoding growth factors are expressed in the thickened dental epithelium around E11.5. They include Fgf8, Fgf9, Bmp2, Bmp4, Bmp7, Shh, Wnt10a, and Wnt10b [25-31]. These epithelial signaling molecules are responsible for the induction of gene expression in the adjacent dental mesenchyme, including Msx1, Msx2, Lef1, Dlx1, Dlx2, Patched (Ptc), Gli1, and Syndecan-1 [25, 28, 31-34,]. At the following bud stage, in response to the epithelial inductive signals, the dental mesenchyme begins to express genes encoding signaling molecules, including BMP4, FGF3, activin- $\beta$ A, and Wnt5a [25, 35-37]. These mesenchymal growth factors act upon the dental epithelium as feedback signals, and also function within the dental mesenchyme, to regulate subsequent tooth development [3]. It is at this stage that dental mesenchyme acquires odontogenic potential. Thus these mesenchymally expressed growth factors might represent components of the odontogenic potential of dental mesenchyme. At E14. 5 tooth development reaches to the cap stage. A number of signaling molecules including BMP2, BMP4, and BMP7 are specifically expressed in the enamel knot which acts as signaling center that controls cell proliferation and 
apoptosis, and determine cusps number and position, and therefore the tooth patterning [38-41].

Of particular interest was the observation that the shift of Bmp4 expression during early tooth development is associated with the shift of the odontogenic potential from the dental epithelium to the mesenchyme [25], suggesting that BMP4 is a component of the odontogenic potential. It was shown that the odontogenic potential of dental epithelium could be partially replaced by recombinant BMP4 protein in the organ culture of dental mesenchyme. Application of BMP4 to the molar dental mesenchyme in culture mimics the effects of the Bmp4-expressing dental epithelium, inducing morphogenetic change of the mesenchyme and activating the expression of transcription factors, such as Msx1, Msx2, Lefl, and Egrl in the mesenchyme [25, 32]. Similar results were obtained from investigations at molecular level on embryonic jaw of the tooth-less bird. It was demonstrated that the early odontogenic signaling pathway is conserved in Aves, and loss of odontogenic Bmp4 expression may be responsible for the early arrest of tooth development in living birds [42, 43]. Furthermore, mesenchymal BMP4 was demonstrated to be responsible for the induction and maintenance of gene expression, such as $S h h$ and $p 21$, in dental epithelium, and for the formation of the enamel knot [39, 44]. Expression of $B m p 4$, together with $B m p 2$ and $B m p 7$, in the enamel knot of the cap stage tooth germ may be responsible for apoptosis in the knot cells [4, 39, 45]. Since mice deficient in Bmp4 die prior to the tooth formation [46], whether or not BMP4 functions as a component of the odontogenic potential in both dental epithelium and dental mesenchyme in vivo remains unknown.

Like other members of the TGF- $\beta$ superfamily, BMP signaling is mediated via heterodimers of transmembrane serine/threonine kinase of type I and type II BMP receptors [47]. In vertebrates, two type I BMP receptors, BMPR-IA (Alk3) and BMPR-IB (Alk6), have been identified, each of which can form heterodimers with type II BMP receptors and bind to BMPs [48]. Once BMP ligands bind to the receptors, the type II receptor phosphorylates the type I receptor which in turn phosphorylates the DNAbinding proteins Smads. The latter translocates into nucleus to regulate target gene expression [49]. BMP signals can also be transduced via ActRIIB and ActR-I (Alk2) [50]. Both Bmpr-IA and Bmpr-IB are expressed in early developing tooth germ [51, 52, Z. Zhang and Chen, unpublished observations]. Mice deficient in Bmpr-IA die before tooth formation [53], while Bmpr-IB mutants do not exhibit a defect in teeth $[54,55]$. Conditional knockout of Bmpr-IA in dental epithelium results in tooth development arrested at the bud stage [56, 57]. These observations further demonstrate that BMP signaling from the mesenchyme to the epithelium is required for the transition of tooth development from the bud to the cap stage [32]. Although Bmpr-IA and Bmpr-IB do not show functional redundancy in embryonic hair follicle development, the case in tooth development is not clear yet [56].

There are eight vertebrate Smad proteins (Smad 1-8) that transducer TGF- $\beta$ signaling. They can be divided into three distinct classes: the receptor-activated Smad (Smad1, Smad2, Smad3, Smad5, and Smad8), the common-mediated Smad (Smad4), and inhibitory Smad (Smad6, Smad7). Among them, Smad1, Smad5 and Smad8 are phosphorylated by BMP type I receptors [58]. All eight Smads are expressed in the developing tooth germ $[59,60 ; \mathrm{X}$. Yu and Chen, unpublished observations]. However, the role of each of them in tooth development is largely elusive, since most knockout mice die before tooth development begins. Using an in vitro organ culture and antisense approach, Chai and his colleagues were able to show that attenuation of Smad2 and $\mathrm{Smad} 7 \mathrm{expression}$ result in abnormal tooth development, indicating that the effectiveness of TGF- $\beta$ signaling in tooth development is highly sensitive to the level of Smad gene expression [59].

\section{Fgfs}

Several members of FGF family are expressed in the early developing tooth germ. They function at distinct steps of odontogenesis, from tooth initiation to the formation of the last tooth cusp [61]. Intensive $F g f 8$ and much weaker $F g f 9$ expression are initially detected in the presumptive dental epithelium before tooth initiation and persist there until the early bud stage. FGF signaling participates in restricting tooth forming sites by inducing the expression of Pax9, Pitx1, and Pitx2 [11, 13, 22]. FGF8 is also responsible for the induction of Barxl in the prospective molar mesenchyme [12]. In addition, FGF8 is also primarily responsible for $\operatorname{Lhx} 6$ and $\operatorname{Lhx} 7$ expression in the odontogenic mesenchyme prior to the initiation and during tooth formation [62]. At the late bud stage and the early cap stage, $F g f 9$ is up-regulated in the primary enamel knot, where Fgf4 is also activated by the Wnt signaling pathway [30, 38, 63]. However, whether FGF8 is a component of the instructive odontogenic potential in the oral epithelium is still obscure, since in mice lacking FGF8 in the oral epithelium, most first branchial arch-derived structures were absent, including the molar, but incisors formed [64]. Another FGF, perhaps FGF9, might rescue incisor formation in the absence of FGF8 [64]. FGF8 may also be responsible for the induction of $F g f 3$ expression in dental mesenchyme [37]. FGF4 and FGF9 stimulate cell proliferation of both dental epithelium and mesenchyme [30, 38]. On the other hand, Fgf3 is expressed in the dental mesenchyme from the E13.5 bud stage on, while FgflO expres- 
sion can be detected in the dental mesenchyme around E14.0 [37]. FGF10 is able to stimulate cell proliferation only in the dental epithelium but not in the mesenchyme [37]. FGF3, however, could stimulate cell proliferation in isolated dental mesenchyme [37]. Mice deficient in either Fgf3 or FgflO did not exhibit major tooth defects [6567]. However, elimination of FGFR2b, the tyrosine kinase receptor for both FGF3 and FGF10, caused an arrest of tooth development at the bud stage $[68,69]$. Thus functional redundancy was proposed for FGF3 and FGF10 in tooth development $[37,63]$.

\section{$\boldsymbol{H h}$}

Among the three members of the hedgehog $(\mathrm{Hh})$ family in vertebrates, Shh is the only Hh ligand to be expressed in teeth. Shh signaling has been implicated in the patterning and growth of a number of vertebrate organs by exerting its short- and long-range effect to activate downstream gene expression during organogenesis [70]. In the developing tooth, $S h h$ transcripts are first detected in the dental epithelium of the dental placode around E11.5 by in situ hybridization [27, 31, 71, 72], suggesting a role for Shh in the initiation of tooth development [27-29]. However, Shh expression can be traced as early as E9.5 in the oral epithelium of transgenic mice bearing an Shh allele knockedin with the $L a c Z$ reporter gene [73]. The factors that induce $S h h$ expression in dental epithelium are currently unknown, but BMP activity in both dental epithelium and dental mesenchyme has been shown to be necessary for the maintenance of Shh expression [44]. The epithelially expressed $S h h$ may regulate thickening and invagination of dental epithelium to form an epithelial tooth bud by stimulating epithelial cell proliferation [29, 74]. This hypothesis is supported by the facts that the application of Shh-soaked beads to E10.5 mouse embryonic mandibles induced the initiation of ectopic epithelial thickening. Blocking of Shh activity in the E10.5 mandible with neutralizing antibody against Shh arrested tooth development at the lamina stage [29, 74]. However, removal of the Shh gene, as well as the Smoothened (Smo) gene which encodes a membrane protein and is essential for the transduction of all Hh signals, in the dental epithelium at E11.75 caused altered cell proliferation, growth, and patterning of the teeth, but tooth initiation and subsequent development occurred anyway $[75,76]$. Although $S h h$ is exclusively expressed in the epithelial compartment during early tooth development, accumulation of Shh protein is found in the mesenchyme of distema region $18 \mathrm{~h}$ after removal of oral epithelium. This observation implies that exclusion of Shh activity from distema mesenchyme may be required for correct tooth initiation at right position in the oral cavity [77]. After the bud stage, Shh expression is confined to the enamel knot at the cap stage, and spreads to the surrounding inner enamel epithelium and the stratum intermedium cells during the following stages [40, 75, 78]. Analyses of knockout mice that are mutants of other genes in the Hh signal pathway further revealed the function of $S h h$ in tooth development. Removal of the Smo gene from the dental epithelium causes abnormally fusion of the first and second molars in both the maxilla and mandible, similar to those molars observed in the Shh conditional knockout mice, but obviously larger than them, suggest that Shh signaling may also operate intra-epithelially besides mediating epithelial-mesenchymal interactions during tooth development [76]. On the other hand, removal of Smo activity from the neural crest derived cells of the first branchial arch (the dental mesenchyme) leads to different tooth phenotypes. In addition to the reduced molars and fused up incisor, the lower incisor is also missed [73]. In the Hh signaling pathway, Dispatched (Disp) functions within the Hh secreting cells by regulating Hh trafficking within the synthesizing cells, controlling the levels of available Hh signal in the embryo $[79,80]$. Displ has been demonstrated essential for transduction of all Hh signals [81]. By taking advantage of a hypomorphic mutant of Disp1, Shh signal in mice can be attenuated at several different levels. When Hh signal is decreased below certain degree, the maxillary incisors are missed [82]. The same tooth phenotype is also characterized in human holoprosencephaly (HPE) that results from reduced Shh signaling [83]. Gli genes encode the transcription effectors of Shh signaling. Single knockout of the three Gli genes did not show obvious tooth defects, but Gli2 and Gli3 double mutants exhibited arrest of tooth development prior to the bud stage [29]. Shh signaling is thus required for the development of early tooth germ.

\section{Wnts}

The vertebrate Wnt gene family represents a large and diverse group of signaling molecules involved in the patterning, proliferation and differentiation of a variety of organs and cell types [84]. They signal through the Frizzled family of receptors, [85-87]. A second type of Wnt receptor is related to the low-density lipoprotein (LDL) receptor and known as LRP5/6 [88, 89]. Wnt binds to both LRP5/6 and Frizzled to form a functional ligand-receptor complex that activates the canonical Wnt/â-catenin pathway and an alternative planar cell polarity pathway [90]. It has become clear that secreted Wnt antagonists play important roles in regulating Wnt signaling. Members of the secreted Frizzled-related protein (sFrp) family appear to function as soluble modulators of Wnt signaling, presumably by competing with membrane Frizzled receptors for the binding of secreted Wnt ligands [91-94]. SFrps se- 
quester Wnts in the extracellular space, preventing activation of both the canonical and the planar polarity Wnt pathways [90]. Members of another family of Wnt antagonist Dickkopf (Dkk) antagonize Wnt signaling by acting as inhibitory ligands of LRP5/6 co-receptors. Dkk binds to LRP5/6 and blocks interaction between Wnt-Frizzled and LRP5/6, preventing the canonical Wnt pathway, but the Wnt-Frizzled complex can still signal via the planar polarity pathway. Thus Dkk would block the $\beta$-catenin pathway (canonical pathway) but leave the cells still capable of responding via the planar polarity pathway.

A number of Wnt genes are expressed in the developing teeth, with most of them restricted solely to the dental epithelium. At E10.5 when tooth forming sites and tooth patterning are determined, $W n t 7 b$ is expressed in the oral epithelium except the presumptive dental epithelium [72]. Ectopic expression of $W n t 7 b$ to the tooth-forming region represses $S h h$ expression and subsequently inhibits tooth formation, but not vice versa [72]. Wnt7b thus seems to interact with Shh signaling to set up the ectodermal boundaries between oral and dental ectoderm, positioning the sites of tooth formation [72]. Wnt10a and Wnt10b are expressed in both molar and incisor epithelium from E11.5 when dental epithelium become thickened, and remain there throughout the bud stage [28]. At the E14.5 cap stage, both genes are expressed in the enamel knot, a putative signaling center for tooth patterning. In addition, Wnt4, Wnt6, and one Wnt receptor $M F z-6$ were expressed in the dental epithelium [36]. In contrast, Wnt5a, sFrp2, and sFrp3 are expressed restrictedly in the dental mesenchyme [36]. The first evidence for a role of Wnt signaling in tooth development came from the analysis of Lefl knockout mice. Mutation in Lefl, a critical component of Wnt signaling pathway, led to an arrest of tooth development at the bud stage [33, 63, 95]. Ectopic expression of Dickkopf (Dkk) driven by the Keratin-14 (K14) promoter in the dental epithelium blocked tooth development before the bud stage, although thickening of the presumptive dental epithelium was observed [96]. Application of exogenous sFRP-3 protein to the explanted presumptive molar region retarded tooth bud formation. Smaller teeth formed in the sFRP-3-treated tooth grafts after subrenal culture [97]. $W n t 3$ is also expressed in the enamel knots. However, overexpression of $W n t 3$ by the $K 14$ promoter in the epithelium did not result in significant change of tooth morphology [98]. Since mice deficient in many Wnt genes, including Wnt1, Wnt2, Wnt3, Wnt3a, Wnt4, and Wnt5a, either die too early for tooth phenotype analysis or do not exhibit a tooth phenotype, the detailed function for each Wnt member in tooth development is not clear at present [84, 99, 100].

\section{TNF}

The most prominent structure of tooth morphogenesis is the temporal epithelium structure, the enamel knot, a signaling center thought to direct tooth morphogenesis and to determine the final tooth morphology [61]. This hypothesis has been strongly supported by the evidence from the studies of Tumor Necrosis Factors (TNF) signal pathway in tooth development. As the first inherited ectodermal deficiency to be described in the mouse [101], Tabby mutant displays a characterized tooth phenotype. While the size and number of molar cusps are significantly reduced, the incisors and the third molar are also frequently missed in these mice [102]. Later, identical tooth phenotype was found in two other spontaneous mouse mutants: Downless and Crinkled [103-105], which together with Tabby turn out to be the different genes in the same signaling pathway. Tabby is identified as Ectodysplasin A1 (EdaA1), a member of TNF family. Downless and Crinkled are the TNF receptor EDAR and EDAR death domain adaptor (EDARADD) respectively [102, 106-112]. Both Edar and Edaradd are expressed in the enamel knot while $E d a$ is expressed in the outer enamel epithelium and can be released by proteolysis $[110,111,113]$. All three mutants show an abnormal enamel knot, and consequently, the molars formed in these mutants show reduced number of cusps with shallow depth $[102,110,112]$. Moreover, the cusp phenotype in Tabby mice could be rescued by applying exogenous EDA protein to the pregnant Tabby mice [114], while overexpression of an activated form of EDAR by the $K 14$ promoter in the epithelium leads to extra cusps in the molars [115]. Similarly transgenic expression of EdaAl driven by the $K 14$ promoter produces extra teeth and extra cusps in the molar $[116,117]$. Taken together, these data suggest that molar morphology is regulated by the activated level of EDA signaling [117]. It has been demonstrated that the EDA signal pathway involves a kinase cascade leading to nuclear factor kappa B (NF- $\mathrm{BB})$ activation [118-122]. The activity of NF- $\mathrm{KB}$ is regulated by its inhibitor (IKB) that again is regulated by IkB kinase (IKK). IKK contains one regulatory subunit IKKg, and two catalyst subunits IKK $\alpha$ and IKK $\beta$. During the cap stage of mouse tooth development, the expression of $N F-\kappa B, I k B$ and $I k k \gamma$ is found in the enamel knot while $I k k \alpha$ and $I k k \beta$ are expressed in the outer edges of dental epithelium. Molars in the Ikk $\alpha$ mutants exhibit abnormal cusp morphology that resembles those found in the Eda, Edar, and Edaradd mutant mice, respectively [123]. Moreover, IKK $\alpha$ shows a NF- $\kappa \mathrm{B}$ independent function in the incisor development. The activation of NF- $\kappa B$ by the EDA signal may be mediated by TNF receptor-associated factor 6 (TRAF6) [124], known to interact with the receptors of 
TNF family and then activate NF-кB [125]. Several Trafs have been shown to be expressed in the dental epithelium [126]. Analysis of the morphology of molar in Traf6 mutant mice reveals more severe cusp abnormalities than those found in the Eda/Edar/Edaradd mutants [124]. Thus, it is proposed that Traf6 would function in two independent ways to activate NF- $\kappa B$ protein. First, TRAF6 binds Troy directly [127], an orphan TNF receptor strongly expressed in the enamel knot [128], and then Troy recruits TRAF6 for the NF- $\kappa B$ activation [129]. On the other hand, EDARADD also shows the capability to recruit TRAF6 for the signal relaying [130]. Since both pathways convert to the NF- $\kappa B$ activation, it explains why similar degree of cusp abnormality is observed in the Traf6 mutant mice and the $N F-\kappa B$ repressed mice. These studies clearly demonstrate the crucial role of the TNF signal pathway in molar cusp formation.

In addition to the function in regulating molar morphogenesis, EDA signaling may also be vital in the maintenance or expansion of the tooth placodes, although it is dispensable in the primary induction of tooth field. Overexpression of EdaAl in the oral epithelium at the early stage rescues the third molar in Tabby mice [131]. However, overexpression of a constitutively active TNF receptor in the oral epithelium occasionally causes missing of the third molar but produces an extra tooth before the first molar at the same time in the transgenic mice [115]. It is thus suggested that the finely balanced signal from EDA/EDAR is required for the expansion of the initial tooth placode for the third molar development. Overexpression of EdaAl in the oral epithelium also results in supernumerary teeth before the first molar in the transgenic mice [116]. Coinciding with the supernumerary tooth formation is the appearance of an extra $S h h$ positive field in the distema region. Hence, it is possible that overexpressed $E d a A 1$ actually maintains this tooth field and consequently leads to tooth formation although it can expand the placodes in a dose-dependent manner in other ectodermal organs [132].

Activin $\beta \mathrm{A}$ is able to induce Edar expression in the dental epithelium where Wnt6 also induces EdaAl expression [112]. Activin $\beta A$ knockout mice show incisor and mandible molar arresting at the bud stage while maxillary molars develop normally [35]. Follistatin is an Activin-antagonizing protein, but can also bind and inhibit the functions of BMP proteins with low affinity [133, 134]. Molars of Follistatin knockout mouse also display shallow and aberrant cusps [135]. Overexpession of Follistatin by the K14 promoter in mice results in lost of the third molar and aberrant cusps of which the upper molars are affected more severely than the lower molars [135]. Since Activin $\beta A$ can induce Edar expression, Follistatin may affect cusp pattern by regulating EDAR level through inhibiting the activity of ActivinbA, and may have the same inhibitory effect on the molecules that function redundantly with ActivinbA in the maxillary molar. Moreover, Follistatin also regulates enamel patterning in the incisors by asymmetrically inhibiting BMP signaling and ameloblast differentiation [136].

\section{Cell-cell signaling}

In addition to mediating tissue-tissue interactions, growth factor signaling also participates in mediating cellcell interactions within epithelial and mesenchymal tissues during organogenesis. This short-range signaling between cells is usually accomplished by one cell possessing a transmembrane receptor and the neighboring cell possessing a membrane-bound ligand. Notch signaling is one such system implicated in tooth morphogenesis [14]. Notch is a large transmembrane receptor known to control cell fate decision and the formation of tissue compartments during embryonic development [137]. Jagged and Delta-like transmembrane proteins are ligands to the Notch receptors. Binding of the membrane-bound ligands to the Notch receptor, which requires intimate cell-cell contacts, triggers the release of the cytoplasmic domain of Notch that subsequently functions as a transcription factor in the nucleus. The expression of several Notch ligands, including Delta1 and Jagged-1, has been detected in developing teeth [138-141]. The expression of Notch-1, -2 , and -3 is detected in the dental epithelium from the initiation stage to the later differentiation stage [138]. However, the expression of these Notch genes is excluded from the basal layer epithelial cells that eventually form ameloblasts. It is thus suggested that ameloblasts may be determined very early at the tooth initiation stage, and the absence of Notch gene expression may be associated with this determination [138].

\section{Crosstalk between different signaling pathways}

As discussed above, many signaling molecules of different families are expressed and used repeatedly throughout the tooth development. They are often expressed either in the same tissue layer or in the adjacent one to mediate cell communication between tissues and within one tissue. These different signaling pathways must be integrated into a regulatory network that operates to orchestrate gene expression. They either function synergistically or antagonistically to regulate gene expression precisely. For example, BMPs and FGFs can up-regulate the same target genes, such as Msxl and Dlx2, but BMPs also counteract the effects of FGFs in the induction of PaxP and Pitx2 in the presumptive dental mesenchyme and epithelium, respectively [11, 22]. Numerous lines of evidence have de- 
monstrated the existence of crosstalk between different signaling pathways. Fgf4 has been shown to be a direct target of Lef1, and can rescue the Lef1 mutant teeth [63], indicating an integration of FGF and Wnt pathways. Wnt pathway is also associated with TNF pathway. This is evidenced by the facts that Wnt6 induces $E d a A l$ expression in the dental epithelium, and a downregulation of Eda is seen in the dental epithelium of the Lefl mutant molar [112]. Furthermore, it was shown that FGF4 or FGF10 can partially rescue the cusp abnormalities of Tabby molar [102]. FGF signaling seems to mediate, at least partially, the Wnt and TNF pathways in tooth development. Together with the evidence that Activin induces Edar expression [112], these results provide evidence for the existence of a regulatory network that integrate FGF, Wnt, TNF, and TGF- $\beta$ signaling pathways in tooth development. In addition, FGF signaling is also linked with the Notch pathway. FGF10 was shown to stimulate the expression of L-Fng, a secretory modulator of Notch signaling, in the stellate reticulum [142].

\section{ROLE OF TRANSCRIPTION FACTORS IN TOOTH DEVELOPMENT}

In situ hybridization experiments have revealed the expression of numerous transcription factors in the developing mouse tooth where the expression patterns of these transcription factors often overlap with those of growth factors, suggesting a potential relationship between the two classes of gene products in inductive interactions [3, 4, 13; also see: http://bite-it.helsinki.fi/]. Knockout studies have provided opportunities to analyze the functions of these transcription factors in tooth development. By far, the bud stage is the most frequent stage at which tooth development arrests in various gene knockout mice, such as Msx1-/-, Lef1-/-, Pax9-/-, and Pitx2-/- mice [33, 143146].

\section{The homeobox-containing genes}

In the mouse, prior to any morphological manifestation of tooth development, a number of homeobox genes, such as Pax9, Msx1, -2, Dlx-3, 5, 6, 7, Barx1, Pitx2, Lhx-6, 7 , are expressed with a specific spatial pattern in the first branchial arch. Based on these observations, a homeobox code hypothesis for tooth pattern formation was proposed [147, 148]. The overlapping expression domains of homeobox genes may subdivide the jaw into different regions, and specify each tooth's position.

Barxl expression is found to be restricted to the molar mesenchyme before and during tooth formation [23]. The antagonistic effects of BMP4 and FGF8 from the overlying oral epithelium are responsible for establishing Barxl expression domains specific in the molar mesenchyme whereas it is implicated in the determination of molar tooth type [12]. Barxl-deficient mice have not been reported, but a recent study using RNAi knock-down demonstrates a critical role for Barxl in the development of molar tooth germ from the bud stage to the cap stage (Song et al., unpublished results).

The expression of Msxl and Msx2 is detected in the developing tooth germ in patterns that correlate with morphogenetic steps in tooth development [149, 150]. Msxl is strongly expressed in the dental mesenchyme including dental papilla and dental follicle throughout the lamina, bud, cap and bell stages of odontogenesis. Msx2 is co-expressed with $M s x l$ in the dental mesenchyme, but a component of $M s x 2$ expression also shifts to the dental epithelium and is restricted to the enamel knot. Mice deficient for Msxl exhibited an arrest of tooth development at the bud stage, while Msx2 mutants manifested later defects in tooth development, including a marked reduction in the stellate reticulum and abnormal patterning of the cusps [143, 151]. Furthermore, tooth development was arrested at the lamina stage in the Msxl-Msx 2 double mutant mice, suggesting a functional redundancy for Msxl and Msx2 in tooth formation [34]. Analyses of gene expression in Msxl mutant tooth germ revealed a down-regulation of a number of genes, including Bmp4, Fgf3, Lef1, Dlx-2, Ptc, syndecan1 , and tenascin $[31,32,34]$. Application of exogenous BMP4 to the Msxl mutant tooth germ in vitro, or ectopic expression of Bmp4 in the Msxl mutant dental mesenchyme via a transgenic approach, partially rescued Msxl mutant tooth phenotype and restored expression of several down-stream genes including Lef1 and Dlx2 [32, 44, $152,153]$. Evidence that mutations in the $M S X 1$ gene in humans cause tooth agenesis and orofacial celfting further demonstrates a vital role of $M s x l$ in odontogenesis [154-160].

Pax9, a member of paired domain family genes, is initially expressed in the presumptive dental mesenchyme at the future sites of tooth formation [11], and continues to be expressed in the dental mesenchyme at the following stages [144]. The confined expression of $\operatorname{Pax} 9$ in the presumptive dental mesenchyme, via the combined effects of BMP and FGF activities, represents an early molecular marker of the dental mesenchyme [11]. Targeted disruption of $\operatorname{Pax} 9$ in mice results in an arrest of tooth development at the bud stage, which is accompanied by a downregulation of Bmp4, Msxl, and Lefl in the dental mesenchyme [144]. Pax9 thus functions upstream of these genes, and controls Bmp4 expression coordinately with $M s x 1$ in the dental mesenchyme. Similarly in humans, mutations in PAX9 cause oligodontia [161].

The expression of Pitx2, a member of the Pitx/RIEG 
family of the Bicoid-related homeobox genes, is regulated positively by FGF8 and negatively by BMP4, in the presumptive dental epithelium $[22,162,163]$. The lack of the Pitx2 gene activity in mice leads to a down-regulation of $F g f 8$ in the dental epithelium [145, 146], indicating a positive feedback loop between Pitx2 and Fgf8. The mutant mice also exhibit an arrest of tooth development at the bud stage. Further investigation revealed that the tooth development is sensitive to the total quantity of Pitx2 regardless of its isoforms. While the dose of Pitx2 increases, intermediate tooth phenotypes that are arrested between the bud stage and normal development were found in different Pitx 2 conditional mutant mice. Moreover, Pitx 2 may also be involved in the regulation of tooth orientation [164].

\section{Other transcription factors}

Lef1 is a member of HMG box family and a nuclear mediator of Wnt signaling [166]. In the developing tooth germ, Lefl is initially expressed in the thickened dental epithelium at E11. At the subsequent bud, cap and bell stages, Lefl transcripts are detected both in the dental mesenchyme and in the immediately adjacent dental epithelium [33]. BMP4 was shown to be responsible for the expression of Lefl in the dental mesenchyme [32, 33]. Loss of Lef1 function resulted in mice lacking teeth. Histological analysis indicates an arrest of tooth development at the bud stage [95]. It was further demonstrated that Lef1 function is needed only transiently in the dental epithelium to control Fgf4 expression in the enamel knot, thus relaying a Wnt signal reception to a cascade of FGF signaling activities $[33,63]$. Application of exogenous FGFs was able to rescue the phenotype of Lef1 mutant teeth [63].

The Cbfa1/Runx 2 protein is a critical transcriptional regulator of the osteoblast differentiation [166]. Null mutation of $C b f a l$ in mice leads to a complete lack of osteoblast differentiation and bone formation [167-169]. Cbfall Runx2 haploinsufficiency in humans causes cleidocranial dysplasia (CCD), a syndrome characterized by generalized bone defects and supernumerary teeth arising from the permanent dentition that fail to erupt [170]. In mice, Cbfal/Runx2 mRNA expression begins in the condensed tooth mesenchyme at the early bud stage (E12 mouse embryos) and continues in the dental papilla through the cap stage until the early bell stage (E16) [171]. Mice deficient in Cbfal/Runx2 exhibit an absence of teeth that are arrested at an aberrant cap stage, and the mandibular molars are more severely affected than the maxillary molars and incisors [171, 172]. FGFs are able to stimulate $C b f a 1 /$ Runx 2 expression in dental mesenchyme, and both $F g f 3$ and FgflO are down-regulated in the Cbfal/Runx2 mutant dental mesenchyme $[171,173]$. However, exogenous
FGFs failed to rescue the tooth phenotype of Cbfal/Runx2 mutants in vitro [173]. Additional studies further indicated that Cbfal/Runx2 is a downstream gene of Msx1. This conclusion is supported by the facts that the expression of Cbfal/Runx2 is down-regulated in the dental mesenchyme of Msxl mutants while Msxl maintains a normal expression pattern in the Cbfal/Runx2 mutant dental mesenchyme [173, 174]. Since Msxl also controls Fgf3 expression in the dental mesenchyme [34], Msxl most likely regulates Cbfal/Runx2 expression via FGF3.

A common function of these transcription factors in the tooth development is to regulate the expression of growth factors. It was therefore suggested that transcription factors participate in epithelial-mesenchymal interactions through linking the signaling loops between tissue layers by responding to inductive signals and regulating the expression of other signaling molecules [3].

\section{STEM CELLS AND TOOTH REGENERATION}

Stem cells are generally defined as cells that have the capacity to self-renew as well as to give rise to differentiated progeny [175]. Stem cells are present in small numbers in many vertebrate adult and fetal tissues, including the hematopoietic system, nervous system, gut, gonads, skin, and olfactory epithelium. They are responsible for normal tissue renewal and for regeneration following damage. It was traditionally thought that only embryonic stem (ES) cells are pluripotent, while adult stem cells are restricted in their differentiative and regenerative potential to the tissues in which they reside [176]. However, this view of adult stem cell potential has been challenged by the recent discoveries that bone marrow stromal cells (BMSCs), when stimulated by differentiated microenvironment cues, have the capacity to differentiate into a range of cell types of different organs, including chondrocytes, osteoblasts, adipocytes, cardiac and skeletal muscle cells, neurons and astrocytes [177-183]. BMSCs, also known as mesenchymal stem cells or colony-forming units fibroblastic, are a population of noncirculating bone marrow-derived cells with remarkable plasticity. They can be isolated based on their adhesive properties, and are capable of clonal expansion in culture [184, 185]. BMSCs share characteristics with other multipotent stem cells, and give rise to differentiated progeny, including both mesenchymal and nonmesenchymal lineages. The properties of rapid expansion in vitro and multipotential of differentiation make BMSCs one of the most important adult stem cell sources for potential therapeutic use and tissue engineering.

Dentinal repair in adult animals takes place through the activity of odontoblasts that differentiate from a precursor cell population existing in the dental pulp tissue. Using 
methodology developed to isolate and characterize BMSCs, clonogenic and highly proliferative dental pulp stem cells (DPSCs) have been isolated from adult human teeth [186]. These DPSCs maintained their high rate of proliferation even after extensive subculturing, and generated a dentin/ pulp-like complex that is composed of mineralized matrix when grafted into the dorsal surface of immunocompromised beige mice [186-188]. However, whether the DPSCs are able to support the formation of a functional tooth has yet to be tested. Both DPSCs and BMSCs are associated with mineralized tissue. Despite the different origins and developmental potentials in vivo, the human DPSCs and BMSCs share many features with respect to their expression of various proteins commonly present in the extracellular matrix of bone and dentin. Both of them are able to form calcified deposits in vitro [186]. Furthermore, microarray analyses of gene expression profiles of the human DPSCs and BMSCs indicate that these two distinct precursor populations have similar level of gene expression for more than 4000 known genes, with only a few differentially expressed ones [189]. In humans, the transition from the deciduous teeth to the permanent teeth is a postnatal development with very unique and dynamic processes. It was found that exfoliated human deciduous tooth contains multipotent stem cells [stem cells from human exfoliated deciduous teeth (SHED)] [190]. SHED are distinct from DPSCs with respect to their capability to differentiate into odontoblasts and generate only dentinlike structure, instead of reconstituting a complete dentinpulp-like complex as DPSCs do. In addition, as compared to DPSCs, SHED has higher proliferation rate and are able to differentiate into a variety of cell types including neural cells and adipocytes. SHED thus might represent a more immature population of multipotent stem cells [190].

Although the isolation of DPSCs in rodents has not been reported, a group of putative stem cells in dental epithelium has been identified in the continuously growing mouse incisor [142]. These stem cells reside in the cervical loop epithelium and give rise to enamel forming ameloblasts. It was also demonstrated that proliferation of the epithelial stem cells is regulated by FGF signals derived from dental mesenchyme [142], and FGF10 in the dental mesenchyme is a survival factor that maintains the stem cell population in the developing incisor germs [191].

Tissue engineering is considered as one of the most powerful approaches to repair or replace an injured tissue or organ in the future. Although a 3-dimensional functional organ has not yet been generated from any stem cells, a functional pancreatic islet-like structure assembled from directed differentiating embryonic stem cells was recently reported [192]. In vitro generation or assembly of an implantable human tooth from stem cells would have extremely significant implications for the dental practice. Animal models of tooth generation in vitro will provide the molecular and cellular basis for the future application in humans. In biodegradable scaffold seeded with single cell suspension dissociated from the third molar tooth germ of six-month old pig jaws, tooth structures formed containing dentin, odontoblast, a well-defined pulp chamber, putative Hertwig's rooth sheath epithelia, and enamel organ [193]. However, the bioengineered teeth are very small and do not conform to the size and shape of the scaffold. It was also shown that a scaffold is not necessary for $e x$ vivo development of tooth explants. Re-aggregates of dissociated mouse molar tooth germ are able to form welldifferentiated teeth underneath the mouse kidney capsule without the need of a scaffold [194; Song et al, unpublished data]. Surprisingly, it was demonstrated recently that mouse stem cells, including ES cells, neural stem cells, and BMSCs, could be induced to reprogram into odontogenic fate to support tooth formation when proper odontogenic signals are provided [195]. These cells, when aggregated and recombined with the E10.5 mouse molar epithelium which possesses the odontogenic potential, could all respond to the inductive signal from the dental epithelium, and initiate odontogenesis that result in tooth fromation [195]. These studies support the idea that the odontogenic process can be initiated in stem cells with non-dental origin when proper odontogenic signals are provided.

\section{CONCLUSION}

The studies on molecular mechanisms underlying tooth morphogenesis in mice have proliferated in the past several years, providing a wealth of data on expression patterns of developmental regulatory molecules as well as their functions [61]. Given the considerable homology between mouse and human odontogenesis as well as the profiles of gene expression, unveiling the molecular basis involved in mouse tooth morphogenesis will provide important insight for studying genetically related dental abnormalities and tooth regeneration in humans. The profiles of gene expression and function in normal tooth development are vital for studying tooth regeneration or reconstitution of a tooth organ because the process of morphogenesis, histogenesis, and cytodifferentiation as well as the molecules involved are likely to be similar. The knowledge gained from adult stem cell biology and molecular regulation of tooth morphogenesis makes it possible to manipulate stem cells to become odontogenic fate. The rapid expansion of our knowledge of experimental embryology, developmental and molecular biology, stem cell biology, and biomimetics makes tooth regeneration a realistic possibility in the near future, which would greatly improve the quality of human life [196]. 


\section{ACKNOWLEDGEMENTS}

The studies described here from the authors' laboratories were supported by grants from the NIH, NSF, and Louisiana Board of Regents to Yi Ping CHEN, and National Natural Science Foundation of China (No. 30270652), and Fujian Provincial Department of Science and Technology (No. 2002I006), China to Yan Ding ZHANG.

\section{REFERENCES}

1 Gurdon JB. The generation of diversity and pattern in animal development. Cell 1992; 68:185-99.

2 Thesleff I, Vaahtokari I, Partanen AM. Regulation of organogenesis: Common molecular mechanisms regulating the development of teeth and other organs. Int J Dev Biol 1995; 39: 35-50.

3 Chen YP, Maas R. Signaling loops in the reciprocal epithelialmesenchymal interactions of mammalian tooth development. In: C-M Chuong, RG Landes, eds. Molecular basis of epithelial appendage morphogenesis. Austin, TX 1998:265-82.

4 Thesleff I, Pispa J. The teeth as models for studies on the molecular basis of the development and evolution of organs. In: CM Chuong, RG Landes, eds. Molecular basis of epithelial appendage morphogenesis. Austin, TX 1998:157-79.

5 Alhadlaq A, Mao JJ. Mesenchymal stem cells: Isolation and therapeutics. Stem Cells Dev 2004; 13:436-48.

6 Thesleff I, Nieminen P. Tooth morphogenesis and cell differentiation. Curr Opin Cell Biol 1996; 8:844-50.

7 Imai H, Osumi-Yamashita N, Ninomiya Y, Eto K. Contribution of early-emigrating midbrain crest cells to the dental mesenchyme of mandibular molar teeth in rat embryos. Dev Biol 1996; 176: 151-65.

8 Kontges G, Lumsden A. Rhombencephalic neural crest segmentation is preserved throughout craniofacial ontogeny. Development 1996; 122:3229-42.

9 Chai Y, Jiang X, Ito Y, et al. Fate of the mammalian cranial neural crest during tooth and mandibular morphogenesis. Development 2000; 127:1671-9.

10 Zhang YD, Wang SS, Song YQ, et al. Timing of odontogenic neural crest cell migration and tooth-forming capability in mice. Dev Dyn 2000; 226:713-8.

11 Neubüser A, Peters H, Ballings R, Martin GR. Antagonistic interactions between FGF and BMP4 signaling pathways: A mechanism for positioning the sites of tooth formation. Cell 1997; 90: 147-55.

12 Tucker AS, Matthews KL, Sharpe PT. Transformation of tooth type induced by inhibition of BMP4 signaling. Science 1998; 282:1136-8.

13 Peters H, Balling R. Teeth: where and how to make them. Trends Genet 1999; 15:59-65.

14 Thesleff I, Mikkola M. The role of growth factors in tooth development. Int Rev Cytol 2002; 217:93-135.

15 Palmer RM, Lumsden AGS. Development of periodontal ligament and alveolar bone in homografted recombinations of enamel organs and papillary, pulpal and follicular mesenchyme in the mouse. Arch Oral Biol 1987; 32:281-9.

16 Mina M, Kollar EJ. The induction of odontogenesis in non- dental mesenchyme combined with early murine mandibular arch epithelium. Arch Oral Biol 1987; 32:123-7.

17 Lumsden AGS. Spatial organization of the epithelium and the role of neural crest cells in the initiation of the mammalian tooth germ. Development 1988; 103 (suppl.):155-69.

18 Kollar EJ, Baird GR. Tissue intereactios in embryonic mouse tooth germs. II. The inductive role of the dental papilla. J Embryol Exp Morphol 1970; 24:173-86.

19 Kollar EJ, Baird GR. The influence of the dental papilla on the development of tooth shape in embryonic mouse tooth germs. J Embryol Exp Morphol 1969; 21:131-48.

20 Yoshikawa DK, Kollar EJ. Recombination experiments on the odontogenic roles of mouse dnetal papilla and dental sac tissues in ocular grafts. Arch Oral Biol 1981; 26:303-7.

21 Koch WE. In vitro differentiation of tooth rudiments of embryonic mice. I. Transfilter interaction of embryonic incisor tissues. Exp Zool 1967; 165:155-70.

22 St Amand TR, Zhang YD, Semina EV, et al. Antagonistic signals between BMP4 and FGF8 define the expression of Pitx1 and Pitx2 in mouse tooth forming anlage. Dev Biol 2000; 217:32332.

23 Tissier-Seta JP, Mucchielli ML, Mark M, Mattei MG, Goridis C, Brunet JJ. Barx1, a new mouse homeodomain transcription factor expressed in cranio-facial ectomesenchyme and the stomach. Mech Dev 1995; 51:3-15.

24 Mitsiadis TA, Angeli I, James, C, Lendahl U, Sharpe PT. Role of Islet1 in the patterning of murine dentition. Development 2003; 130:4451-60.

25 Vainio S, Karavanova I, Jowett A, Thesleff I. Identification of BMP-4 as a signal mediating secondary induction between epithelial and mesenchymal tissues during early tooth development. Cell 1993; 75:45-58.

26 Heikinheimo M, Lawshe A, Shackleford MG, Wilson DB, MacArthur CA. Fgf-8 expression in the post-gastrulation muse suggest role in the development of the face, limb, and central nervous system. Mech Dev 1994; 48:129-38.

27 Bitgood MJ, McMahon AP. Hedgehog and BMP genes are coexpressed at many diverse sites of cell-cell interactions in the mouse embryo. Dev Biol 1995; 172:126-38.

28 Dassule HR, McMahon AP. Analysis of epithelial-mesenchymal interactions in the initial morphogenesis of the mammalian tooth. Dev Biol 1998; 202:215-27.

29 Hardcastle Z, Mo R, Hui, CC, Sharpe PT. The Shh signaling pathway in tooth development: defects in Gli2 and Gli3 mutants. Development 1998; 125:2803-11.

30 Kettunen P, Thesleff I. Expression and function of FGFs-4, -8, and -9 suggest functional redundancy and repetitive use as epithelial signals during tooth morphogenesis. Dev Dyn 1998; 211: 256-68.

31 Zhang YD, Zhao X, Hu Y, et al. Msx 1 is required for the induction of Patched by Sonic hedgehog in the mammalian tooth germ. Dev Dyn 1999; 215:45-53.

32 Chen YP, Bei M, Woo I, Satokata I, Mass R. Msx 1 controls inductive signaling in mammalian tooth morphogenesis. Development 1996; 122:3035-44.

33 Kratochwil K, Dull M, Farinas I, Galcera J, Grosschedl R. Lef1 expression is activated by BMP-4 and regulates inductive tissue interactions in tooth and hair development. Genes Dev 1996; 10: 1382-94. 
34 Bei M, Maas R. FGFs and BMP4 induce both Msx1-independent and Msx1-dependent signaling pathways in early tooth development. Development 1998; 125:4325-33.

35 Ferguson CA, Tucker AS, Christensen L, et al. Activin is an essential early mesenchymal signal in tooth development that is required for patterning of the murine dentition. Genes Dev 1998; 12:2636-49.

36 Sarkar L, Sharpe PT. Expression of Wnt signaling pathway genes during tooth development. Mech Dev 1999; 85:197-200.

37 Kettunen P, Laurikkala J, Itaranta P, et al. Association of FGF3 and FGF-10 with signaling networks regulating tooth morphogenesis. Dev Dyn 2000; 219:322-32.

38 Jernvall J, Kettunen P, Karavanova I, Martin LB, Thesleff I. Evidence for the role of the enamel knot as a control center in mammalian tooth cusp formation: non-dividing cells express growth stimulating Fgf-4 gene. Int J Dev Biol 1994; 38:463-9.

39 Jernvall J, Abert T, Kettunen P. Keranen S, Thesleff I. The life history of embryonic signaling center: BMP-4 induces p21 and is associated with apoptosis in the mouse tooth enamel knot. Development 1998; 125:161-9.

40 Vaahtokari A, Åbert T, Jernvall J, Keränen S, Thesleff I. The enamel knot as a signaling center in the developing mouse tooth Mech Dev 1996; 54:39-43.

41 Coin R, Lesot H, Vonesch JL, Haikel Y, Ruch JV. Aspects of cell proliferation kinetics of the inner dental epithelium during mouse molar and incisor morphogenesis: a reappraisal of the role of the enamel knot area. Int J Dev Biol 1999; 43:261-7

42 Chen YP, Zhang YD, Jiang TX, et al. Conservation of early odontogenic signaling pathways in Aves. Proc Natl Acad Sci U S A 2000; 97:10044-9.

43 Zhang YD, Lin W, Gao J. The molecular mechanism for positioning tooth forming sites is conserved in Aves. Dev Reprod Biol 2001; 10:1-11.

44 Zhang YD, Zhang ZY, Zhao X, et al. A new function of BMP4: Dual role for BMP4 in regulation of Sonic hedgehog expression in the mouse tooth germ. Development 2000; 127:1431-43.

45 Vaahtokari A, Aberg T, Thesleff I. Apoptosis in the developing tooth: association with an embryonic signaling center and suppression by EGF and FGF-4. Development 1996; 122:121-9.

46 Winnier G, Blessing M, Labosky PA, Hogan BLM. Bone morphogenetic protein- 4 is required for mesoderm formation and patterning in the mouse. Genes Dev 1995; 9:2105-16.

47 Massagué J. TGF $\beta$ signaling: receptors, transducers, and Mad proteins. Cell 1996; 85:127-38.

48 Hogan BLM. Bone morphogenetic proteins: multifunctional regulators of vertebrate development. Genes Dev 1996; 10:1580-94.

49 Whitman M. Smads and early developmental signaling by the TGFâ superfamily. Genes Dev 1998; 12:2445-62.

50 Kawabata M, Imamura T, Miyazono K. Signal transduction by bone morphogenetic proteins. Cytokine Growth Factor Rev 1998; 9:49-61.

51 ten Dijike P, Yamashita H, Sampath TK, et al. Identification of type I receptors for osteogenic protein-1 and bone morphogenetic protein-4. J Biol Chem 1994; 169:16985-8.

52 Dewulf N, Verschueren K, Lonnoy O, et al. Distinct spatial and temporal expression patterns of two type I receptors for Bone Morphogenetic Proteins during mouse embryogenesis. Endocrinology 1995; 136:2652-63.

53 Mishina Y, Suzuki A, Ueno N, Behringer RR. Bmpr encodes a type I bone morphogenetic protein receptor that is essential for gastrulation during mouse embryogenesis. Genes Dev 1995; 9: 3027-37.

54 Bauer ST, Mai JJ, Dymecki SM. Combinatorial signaling through BMP receptor IB and GDF5: shaping of the distal mouse limb and the genetics of distal limb diversity. Development 2000; 127:605-19.

55 Yi SE, Daluiski A, Pederson R, Rosen V, Lyons KM. The type I BMP receptor BMPRIB is required for chondrogenesis in the mouse limb. Development 2000; 127:621-30.

56 Andl T, Ahn K, Kairo A, et al. Epithelial Bmprla regulates differentiation and proliferation in postnatal hair follicles and is essential for tooth development. Development. 2004; 131:225768.

57 Liu W, Sun X, Braut A, et al. Distinct function for Bmp signaling in lip and palate fusion in mice. Development 2005; 132:145361.

58 Derynck R, Zhang YE. Smad-dependent and Smad-independent pathways in TGF- $\beta$ family signaling. Nature 2003 ; 425:577-84.

59 Ito Y, Zhao J, Moghare A, et al. Antagonistic effects of Smad2 versus Smad7 are sensitive to their expression level during tooth development. J Biol Chem 2001; 276:44163-72.

$60 \mathrm{Xu}$ X, Jeong L, Han J, et al. Developmental expression of Smad17 suggests critical function of TGF-beta/BMP signaling in regulating epithelial-mesenchymal interaction during tooth morphogenesis. Int J Dev Biol 2003; 47:31-9.

61 Jernvall J, Thesleff I. Reiterative signaling and patterning during mammalian tooth morphogenesis. Mech Dev 2000; 92: 19-29.

62 Grigoriou M, Tucker AS, Sharpe PT, Pachnis V. Expression and regulation of Lhx6 and Lhx7, a novel subfamily of LIM homeodomain encoding genes, suggests a role in mammalian head development. Development 1998; 125:2063-74

63 Kratochwil K, Galceran J, Tontsch S, Roth W, Grosschedl R. FGF4, a direct target of LEF1 and Wnt signaling, can rescue the arrest of tooth organogenesis in Lef1-/- mice. Genes Dev 2002; 16:3173-85.

64 Trumpp A, Depew MJ, Rubenstein JLR, Bishop M, Martin GR. Cre-mediated gene inactivation demonstrates that FGF8 is required for cell survival and patterning of the first branchial arch. Genes Dev 1999; 13:3136-48.

65 Mansour SL, Goddard JM, Capecchi MR. Mice homozygous for a targeted disruption of the proto-oncogene int-2 have developmental defects in the tail and inner ear. Development 11993; 17:13-28.

66 Min H, Danilenko DM, Scully SA, et al. Fgf-10 is required for both limb and lung development and exhibits striking functional similarity to Drosophila branchless. Genes Dev 1998; 12:315661

67 Sekine K, Ohuchi H, Fujiwara M, et al. Fgf10 is essential for limb and lung formation. Nat Genet 1999; 21:138-41.

68 Celli G, LaRochelle WJ, Mackem S, Sharp R, Merlino G. Soluble dominant-negative receptor uncovers roles for fibroblast growth factors in multi-organ induction and patterning. EMBO J 1998; 17:1642-55.

69 De Moerlooze L, Spencer-Dene B, Revest J-M, et al. An important role for the IIIb form of fibroblast growth factor receptor 2 (FGFR2) in mesenchymal-epithelial signaling during mouse organogenesis. Development 2000; 127:4775-85.

70 Johnson RL, Tabin C. The long and short hedgehog signaling. 
Cell 1995; 81:313-6.

71 Keränen SVE, Åberg T, Kettunen P, Thesleff I, Jernvall J. Association of developmental regulatory genes with the development of different molar tooth shapes in two species of rodents. Dev Genes Evol 1998; 208:477-86.

72 Sarkar L, Cobourne M, Naylor S, et al. Wnt/Shh interactions regulate ectodermal boundary formation during mammalian tooth development. Proc Natl Acad Sci USA 2000; 97:4520-4.

73 Jeong J, Mao J, Tenzen T, Kottmann AH, McMahon AP. Hedgehog signaling in the neural crest cells regulates the patterning and growth of facial primordia. Genes Dev 2004; 18:937-51.

74 Cobourne MT, Hardcastle Z, Sharpe PT. Sonic hedgehog regulates epithelial proliferation and cell survival in the developing tooth germ. J Dent Res 2001; 80:1974-9.

75 Dassule HR, Lewis P, Bei M, Maas R, McMahon AP. Sonic hedgehog regulates growth and morphogenesis of the tooth. Development 2000; 127:4775-85.

76 Gritli-Linde A, Bei M, Maas R, et al. Shh signaling within the dental epithelium is necessary for cell proliferation, growth and polarization. Development 2002; 129:5323-37.

77 Cobourne MT, Miletich I, Sharpe PT. Restriction of sonic hedgehog signalling during early tooth development. Development 2004; 131:2875-85.

78 Koyama E, Yamaai T, Iseki S, et al. Polarizing activity, Sonic hedgehog, and tooth development in embryonic and postnatal mouse. Dev Dyn 1996; 206:59-72.

79 Burke R, Nellen D, Bellotto M, et al. Dispatched, a novel sterolsensing domain protein dedicated to the release of cholesterolmodified hedgehog from signaling cells. Cell 1999; 99:803-15.

80 Gallet A, Rodriguez R, Ruel L, Therond PP. Cholesterol modification of hedgehog is required for trafficking and movement, revealing an asymmetric cellular response to hedgehog. Dev Cell 2003; 4: 191-204.

81 Ma Y, Erkner A, Gong, R, et al. Hedgehog-Mediated patterning of the mammalian embryo requires transporter-like function of Dispatched. Cell 2002; 111:63-75.

82 Tian H, Tenzen T, McMahon AP. Dose dependency of Displand genetic interaction between Disp1 and other hedgehog signaling components in the mouse. Development 2004; 131:4021-33.

83 Wallis DE, Muenke M. Molecular mechanisms of holoprosencephaly. Mol Genet Metab 1999; 68:126-38.

84 Cadigan KM, Nusse R. Wnt signaling: a common theme in animal development. Genes Dev 1997; 11:3286-305.

85 Bhanot P, Brink M, Samos CH, et al. A new member of the frizzled family from Drosophila functions as a Wingless receptor. Nature 1996; 382:225-30.

86 Yang-Snyder J, Miller JR, Brown JD, Lai CJ, Moon RT. A frizzled homolog functions in a vertebrate Wnt signaling pathway. Curr Biol 1996; 6:1302-6.

87 He X, Saint-Jeannet JP, Wang Y, Nathans Dawid I, Varmus HA. A member of the Frizzled protein mediating axis induction by Wnt-5A. Science 1997; 275:1652-4.

88 Tamai K, Semenov M, Kato Y, et al. LDL-receptor-related proteins in Wnt signaling transduction. Nature 2000; 407:530-5.

89 Pinson KI, Brenna J, Monkley S, Avery BJ, Skarnes WC. An LDL receptor-related protein mediates Wnt signaling in mice. Nature 2000; 407:535-8

90 Zorn AM. Wnt signaling: antagonistic dicckopfs. Curr Biol 2001; 11:R592-5.
91 Rattner A, Hsieh JC, Smallwood PM, et al. A family of secreted proteins contains homology to the cysteine-rich ligand-binding domain of frizzled receptors. Proc.Natl Acad Sci U S A 1997; 94: 2859-63.

92 Leyns L, Bouwmeester T, Kim SH, Piccolo S, De Robertis EM. Frzb-1 is a secreted antagonist of Wnt signaling expressed in the Spemann organizer. Cell 1997; 88:747-56.

93 Moon RT, Brown JD, Yang-Snyder JA, Miller, JR. Structurally related receptors and antagonists compete for secreted Wnt ligands. Cell 1997; 88:725-8.

94 Melkonyan HS, Chang WC, Shapiro JP, et al. SAPRs: a family of secreted apoptosis-related proteins. Proc Natl Acad Sci U S A 1997; 94:13636-41.

95 van Genderen C, Okamura R., Farinas I, et al. Development of several organs that require inductive epithelial-mesenchymal interactions is impaired in LEF-1 deficient mice. Genes Dev 1994; 8:2691-703.

96 Andl T, Reddy ST, Gaddapara T, Millar SE. WNT signals are required for the initiation of hair follicle development. Dev Cell 2002; 2:643-53.

97 Sarkar L, Sharpe PT. Inhibition of Wnt signaling by exogenous Mfrzb1 protein affects molar tooth size. J Dent Res 1999; 79: 920-5.

98 Millar SE, Koyama E, Reddy ST, et al. Over- and ectopic expression of Wnt 3 causes progressive loss of ameloblasts in postnatal mouse incisor teeth. Connect Tissue Res. 2003; 44 (Suppl 1): $124-9$.

99 Liu P, Wakamiya M, Shea MJ, et al. Requirement for Wnt3 in vertebrate axis formation. Nat Genet 1999; 22:361-5.

100 Yamaguchi TP, Bradley A, McMahon AP, Jones S. A Wnt5a pathway underlies outgrowth of multiple structures in the vertebrate embryo. Development 1999; 126:1211-23.

101 Falconer DS. A totally sex-linked gene in the house mouse. Nature 1952; 169:664-5.

102Pispa J, Jung HS, Jernvall J, et al. Cusp patterning defect in Tabby mouse teeth and its partial rescue by FGF. Dev Biol 1999; 216:521-34.

103 Gruneberg H. Genes and genotypes affecting the teeth of the mouse. J Embryol Ex Morphol 1965; 14:137-59.

104Sofaer JA. Aspects of the tabby-crinkled-downless syndrome I. The development of tabby teeth. J Embryol Exp Morphol 1969; 22:181-205.

105 Sofaer JA. Short communication: The teeth of the 'Sleek' mouse. Arch Oral Biol 1977; 22:299-301.

106 Kere J, Srivastava AK, Montonen O, et al. X-linked anhidrotic (hypohidrotic) ectodermal dysplasia is caused by mutation in a novel transmembrane protein. Nat Genet 1996; 13:409-16.

107 Ferguson BM, Brockdorff N, Formstone E, et al. Cloning of tabby, the murine homologue of the human EDA gene: evidence for a membrane associated protein with a short collagenous domain. Hum Mol Genet 1997; 6:1589-94.

108 Srivastava AK, Pispa J, Hartung AJ, et al. The tabby phenotype is caused by mutations in a mouse homologue of the EDA gene that reveals novel mouse and human exons and encodes a protein (ectodysplasin-A) with collagenous domains. Proc Natl Acad Sci U S A 1997; 94:13069-74.

109Monreal AW, Ferguson BM, Headon DJ, et al. Mutations in the human homolog of the mouse dl cause autosomal recessive and dominant hypohidrotic ectodermal dysplasia. Nat Genet 1999; 
22:366-9.

110Tucker AS, Headon DJ, Schneider P, et al. Edar/Eda interactions regulate enamel knot formation in tooth morphogenesis. Development 2000; 127:4691-700.

111 Headon DJ, Emmal SA, Ferguson BM, et al. Gene defect in ectodermal dysplasia implicates a death domain adapter in development. Nature 2001; 414:913-6.

112Laurikkala J, Mikkola M, Mustonen T, et al. TNF signaling via the ligand-receptor pair ctodysplasin and edar controls the function of epithelial signaling centers and is regulated by Wnt and activin during tooth organogenesis. Dev Biol 2001; 229:443-55.

113Elomaa O, Pulkkinen K, Hannelius U, et al. Ectodysplasin is released by proteolytic shedding and binds to the EDAR protein. Hum Mol Genet 2001; 10:953-62.

114 Gaide O, Schneider P. Permanent correction of an inherited ectodermal dysplasia with recombinant EDA. Nat Med 2003; 9: 614-8.

115 Tucker AS, Headon DJ, Courtney JM, Overbeek P, Sharpe PT. The activation level of the TNF family receptor, Edar, determines cusp number and tooth number during tooth development. Dev Biol 2004; 268:185-94.

116 Mustonen T, Pispa J, Mikkola ML, et al. Stimulation of ectodermal organ development by Ectodysplasin-A1. Dev Biol 2003; 259:123-36.

117Kangas A, Evens A, Thesleff I, Jernvall J. Nonindependence of mammalian dental characters. Nature 2004; 423:211-4.

118 Yan M, Wang LC, Hymowitz SG, et al. Two amino acid molecular switch in an epithelial morphogen that regulates binding to two distinct receptors. Science 2000; 290:523-7.

119Doffinger R, Smahi A, Bessia C, et al. X-linked anhidrotic ectodermal dysplasia with immunodeficiency is caused by impaired NF-kappaB signaling. Nat Genet 2001; 27:277-85.

120 Kumar A, Eby MT, Sinha S, Jasmin A, Chaudhary PM. The Ectodermal Dysplasia Receptor Activates the Nuclear Factor$\mathrm{kB}, \mathrm{JNK}$, and Cell Death Pathways and Binds to Ectodysplasin A. J Biol Chem 2001; 276:2668-77.

121 Schmidt-Ullrich R, Aebischer T, Hulsken J, et al. Requirement of NF-kappaB/Rel for the development of hair follicles and other epidermal appendices. Development 2001; 128:3843-53.

122 Koppinen P, Pispa J, Laurikkala J, Thesleff I, Mikkola ML. Signalling and subcellular localization of the TNF receptor Edar. Exp Cell Res 2001; 269:180-92.

123Ohazama A, Hu Y, Schmidt-Ullrich R, et al. A dual role for Ikk $\alpha$ in tooth development. Developmental Cell 2004; 6:219-27.

124Ohazama A, Courtney J-M, Tucker AS, et al. Traf6 is essential for murine tooth cusp morphogenesis. Dev Dyn 2004; 229:1315.

125Chung JY, Park YC, Ye H, Wu H. All TRAFs are not created equal: common and distinct molecular mechanisms of TRAFmediated signal transduction. J Cell Sci 2002; 115:679-88.

126Ohazama A, Courtney JM, Sharpe PT. Expression of TNFreceptor-associated factor genes in murine tooth development. Gene Expr Patterns 2003; 3:127-9.

127Naito A, Yoshida H, Nishioka E, et al. TRAF6-deficient mice display hypohidrotic ectodermal dysplasia. Proc Natl Acad Sci U S A 2002; 99:8766-71.

128Pispa J, Mikkola ML, Mustonen T, Thesleff I. Ectodysplasin, Edar and TNFRSF19 are expressed in complementary and overlapping patterns during mouse embryogenesis. Gene Expr Pat- terns 2003; 3:675-9.

129Kojima T, Morikawa Y, Copeland NG, et al. TROY, a newly identified member of the tumor necrosis factor receptor superfamily, exhibits a homology with Edar and is expressed in embryonic skin and hair follicles. J Biol Chem 2000; 275:207427.

130 Yan M, Zhang Z, Brady JR, et al. Identification of a novel death domain-containing adaptor molecule for ectodysplasin-A receptor that is mutated in crinkled mice. Curr Biol 2002; 12:409-13.

131 Srivastava AK, Durmowicz MC, Hartung AJ, et al. Ectodysplasin-A1 is sufficient to rescue both hair growth and sweat glands in Tabby mice. Hum Mol Genet 2001; 10:2973-81.

132 Mustonen T, Ilmonen M, Pummila M, et al. Ectodysplasin A1 promotes placodal cell fate during early morphogenesis of ectodermal appendages. Development. 2004; 131:4907-19.

133Iemura S, Yamamoto TS, Takagi C, et al. Direct binding of follistatin to a complex of bone-morphogenetic protein and its receptor inhibits ventral and epidermal cell fates in early Xenopus embryo. Proc Natl Acad Sci U S A 1998; 95:9337-42.

134Balemans W, Van Hul W. Extracellular regulation of BMP signaling in vertebrates: a cocktail of modulators. Dev Biol 2002; 250: 231-50.

135 Wang XP, Suomalainen M, Jorgez CJ, et al. Modulation of activin/ bone morphogenetic protein signaling by follistatin is required for the morphogenesis of mouse molar teeth. Dev Dyn 2004; 231:98-108.

136Wang XP, Suomalainen M, Jorgez CJ, et al. Follistatin regulates enamel patterning in mouse incisors by asymmetrically inhibiting BMP signaling and ameloblast differentiation. Dev Cell 2004; 7:719-30.

137 Artavanis-Tsakonas S, Rand MD, Lake RJ. Notch signaling: Cell fate control and signal integration in development. Science 1999; 284:770-6.

138 Mitsiadis, T. Lardelli, M, Lendahl U, Thesleff I. Expression of Notch 1, 2, and 3 is regulated by epithelial-mesenchymal interactions and retinoic acid in the developing mouse tooth and associated with determination of ameloblast cell fate. J Cell Biol 1995; 130:407-18.

139Mitsiadis T, Henrique D, Thesleff I, Lendahl U. Mouse Serrate1 (Jagged-1) expression in the developing tooth is regulated by epithelial-mesenchymal interactions and fibroblast growth factor-4. Development 1997; 124:1473-83.

140Mitsiadis T, Hirsinger E, Lendahl U, Goridis C. Delta-Notch signaling in odontogenesis: Correlation with cytodifferentiation and evidence for feedback regulation. Dev Biol 1998; 204:42031.

141 Mustonen T, Tummers M, Mikami T, et al. Lunatic fringe, FGF, and BMP regulate the Notch pathway during epithelial morphogenesis of teeth. Dev Biol 2002; 248:281-93.

142 Harada H, Kettunen P, Jung H-S, et al. Localization of putative stem cells in dental epithelium and their association with Notch and FGF signaling. J Cell Biol 1999; 147:105-20.

143Satokata I, Maas R. Msx-1 deficient mice exhibit cleft palate and abnormalities of craniofacial and tooth development. Nat Genet 1994; 6:348-56.

144Peters H, Neubuser A, Kratochwil K, Balling R. Pax9-deficient mice lack pharyngeal pouch derivatives and teeth and exhibit craniofacial and limb abnormalities. Genes Dev 1998; 12:273547. 
145Lin C, Kioussi C, O’Connel S, ET AL. Pitx2 regulates lung asymmetry, cardiac positioning and pituitary and tooth morphogenesis. Nature 1999; 401:279-82.

146Lu MF, Pressman C, Dyer R, Johnson RL, Martin JF. Function of Rieger syndrome gene in left-right asymmetry and craniofacial development. Nature 1999; 401:276-8.

147 Sharpe PT. Homeobox genes and orofacial development. Connect Tissue Res 1995; 32:17-25.

148Thomas BL, Tucker AS, Qui M, ET AL. Role of Dlx-1 and Dlx2 genes in patterning of the murine dentition. Development 1997; 124:4811-8.

149MacKenzie A, Leeming GL, Jowett AK, Ferguson MWJ, Sharpe PT. The homeobox gene Hox7.1 has specific regional and temporal patterns during early murine craniofacial embryogenesis, especially tooth development in vivo and in vitro. Development 1991; 111:269-85.

150MacKenzie A, Ferguson MWJ, Sharpe PT. Expression patterns of homeobox gene, Hox-8, in the mouse embryo suggest a role in specifying tooth initiation and shape. Development 1992; 115: 403-40.

151 Satokata I, Ma L, Ohshima H, et al. Msx-2 deficiency in mice causes pleiotropic defects in bone growth and ectodermal organ formation. Nat Genet 2000; 21:138-41.

152Bei M, Kratochwil K, Maas R. BMP4 rescues a non-cell-autonomous function of Msx 1 in tooth development. Development 2000; 127:4711-8.

153Zhao X, Zhang ZY, Song Y, et al. Transgenically ectopic expression of Bmp4 to the Msx1 mutant dental mesenchyme restores downstream gene expression but represses Shh and Bmp2 in the enamel knot of wild type tooth germ. Mech Dev 2000; 99:29-38.

154 Vastardis H, Karimbux N, Guthua SW, Seidman JG, Seidman CE. A human MSX1 homeodomain missense mutation causes selective tooth agenesis. Nat Genet 1996; 13:417-21.

155Lidral AC, Romitti PA, Basart AM, et al. Association of MSX1 and TGFB3 with nonsydromic celfting in humans. Am J Hum Genet 1998; 63:557-68.

156 Van den Boogaard MJ, Dorland M, Beemer FA, van Amestel HK. MSX1 mutation is associated with orofacial clefting and tooth agenesis in humans. Nat Genet 2000; 24:242-3.

157 Beaty TH, Wang H, Hetmanski JB et al. A case-control study of nonsyndromic oral clefts in Maryland. Ann Epidemiol 2001; 11: 434-42.

158Blanco R, Chakraborty R, Barton SA, et al. Evidence of a sexdependent association between the MSX1 locus and nonsyndromic cleft lip with or without cleft palate in the Chilean population. Hum Biol 2001; 73:81-9.

159 Jumlongras D, Bei M, Stimson JM, et al. A nonsense mutation in MSX1 causes Witkop syndrome. Am J Hum Genet 2001; 69: 67-74.

160 Lidral AC, Reising BC. The role of MSX1 in human tooth agenesis. J Dent Res 2002; 81:274-8.

161 Stockton DW, Das P, Goldenberg M, D'Souza RN, Patel PI. Mutation of PAX9 is associated with oligodontia. Nat Genet 2002; 24:18-9.

162 Semina EV, Reiter RS, Leysens NJ, et al. Cloning and characterization of a novel bicoid-related homeobox transcription factor gene, RIEG, involved in Rieger syndrome. Nat Genet 1996; 14: 392-9.

163 Mucchielli M-L, Mitsiadis TA, Raffo S, et al. Mouse Otlx2/
RIEG expression in the odontogenic epithelium precedes tooth initiation and requires mesenchyme-derived signals for its maintenance. Dev Biol 1997; 189:275-84.

164Liu W, Selever J, Lu MF, Martin JF. Genetic dissection of Pitx2 in craniofacial development uncovers new functions in branchial arch morphogenesis, late aspects of tooth morphogenesis and cell migration. Development 2003; 130:6375-85.

165 Grosschedl R, Giese K, Page J. HMG domain proteins: Architectural elements in the assembly of neucleoprotein structures. Trends Genet 1994; 6:348-56.

166Ducy P. Cbfa1: a molecular switch in osteoblast biology. Dev Dyn 2000; 219:461-71.

167Ducy P, Zhang R, Geoffroy V, Ridall AL, Karsenty G. Osf2/ Cbfa1: a transcriptional activator of osteoblast differentiation. Cell 1997; 9:747-54.

168 Komori T, Yagi H, Nomura S, et al. Targeted disruption of Cbfa1 results in a complete lack of bone formation owing to maturational arrest of osteoblasts. Cell 1997; 89:755-64.

169Otto F, Thornell AP, Crompton T, et al. Cbfa1, a candidate gene for cleidocranial dysplasia syndrome, is essential for osteoblast differentiation and bone development. Cell 1997; 89:765-71.

170Mundlos S, Otto F, Mundlos C, et al. Mutations involving the transcription factor CBFA1 cause cleidocranial dysplasia. Cell 1997; 89:773-9.

171D'Souza RN, Aberg T, Gaikwad J, et al. Cbfa1 is required for epithelial-mesenchymal interactions regulating tooth development in mice. Development 1999; 126:2911-20.

172 Åberg T, Cavender A, Gaikwad JS, et al. Phenotypic changes in dentition of Runx2 homozygote-null mutant mice. J Histochem Cytochem 2004; 52:131-9.

173 Aberg T, Wang XP, Kim JH, et al. Runx2 mediates FGF signaling from epithelium to mesenchyme during tooth morphogenesis. Dev Biol 2004; 270:76-93.

174 Zhang ZY, Song YQ, Zhang X, et al. Msx1/Bmp4 genetic pathway regulates mammalian alveolar bone formation via induction of Dlx5 and Cbfa1. Mech Dev 2003; 120:1469-79.

175 Van der Kooy D, Weiss S. Why stem cells? Science 2000; 287: 1439-41.

176Blau HM, Brazelton TR, Weimann JM. The evolving concept of a stem cell: Entity or function? Cell 2001; 105:829-41.

177 Kopen GC, Prockop DJ, Phinney DG. Marrow stromal cells migrate throughout forebrain and cerebellum, and they differentiate into astrocytes after injection into neonatal mouse brain. Proc Natl Acad Sci U S A 1999; 96:10711-6.

178Pittenger MF, Mackay AM, Beck SC, et al. Multilineage potential of adult human mesenchymal stem cells. Science 1999; 284: 143-7.

179Liechty KW, MacKenzie TC, Shaaban AF, et al. Human mesenchymal stem cells engraft and demonstrate site-specific differentiation after in utero transplantation in sheep. Nature Med 2000; 6:1282-6.

180Sanchz-Ramos J, Song S, Cardozo-Pelaez F, et al. Adult bone marrow stromal cells differentiate into neural cells in vitro. Exp Neurol 2000; 164:247-56.

181 Woodbury D, Schwarz EJ, Prockop DJ, Black IB. Adult rat and human bone marrow stromal cells differentiate into neurons. J Neurosci Res 2000; 61:364-70.

182 Krause D, Theise ND, Collector MI, et al. Multi-organ, multilineage engraftment by a single bone marrow-derived stem cell. 
Cell 2001; 105:369-77.

183 Orlic D, Kajstura J, Chimenti S, et al. Bone marrow cells regenerate infarcted myocardium. Science 2001; 410:701-5.

184 Prockop DJ. Marrow stromal cells as stem cells for nonhematopoitic tissues. Science 1997; 276:71-4.

185 Javazon EH, Colter DC, Schwarz EJ, Prockop DJ. Rat marrow stromal cells are more sensitive to plating density and expand more rapidly from single-cell-derived colonies than human marrow stromal cells. Stem Cells 2001; 19:219-25.

186Gronthos S, Mankani M, Brahim J, Robey PG, Shi S. Postnatal human dental pulp stem cells (DPSCs) in vitro and in vivo. Proc Natl Acad Sci U S A 2000; 97:13625-30.

187 Gronthos S, Brahim J, Li W, et al. Stem cell properties of human dental pulp stem cells. J Dent Res 2002; 81:531-5.

188Batouli S, Miura M, Brahim J, et al. Comparison of stem-cellmediated osteogenesis and dentinogenesis. J Dent Res 2003; 82: 976-81.

189Shi S, Robey PG, Gronthos S. Comparison of human dental pulp and bone marrow stromal stem cells by cDNA microarray analysis. Bone 2001; 29:532-9.
190Miura M, Gronthos S, Zhao M, et al. SHED: Stem cells from human exfoliated deciduous teeth. Proc Natl Acad Sci U S A 2003; 100:5807-12.

191 Harada H. Toyono T, Toyoshima K, et al. FGF10 maintains stem cell compartment in developing mouse incisors. Development 2002; 129:1533-41.

192Lumelsky N, Blondel O, Laeng P, et al. Differentiation of embryonic stem cells to insulin-secreting structures similar to pancreatic islets. Science 2001; 292:1389-94.

193 Young CS, Terada S, Vacanti JP, et al. Tissue engineering of complex tooth structures on biodegradable polymer scaffolds. J Dent Res 2002; 81:695-700.

194 Yamamoto H, Kim EJ, Cho SW, Jung HS. Analysis of tooth formation by reaggregated dental mesenchyme from mouse embryo. J Electro Microsc 2003; 52:559-66.

195Ohazama A, Modino SAC, Miletich I, Sharpe PT. Stem-cellbased tissue engineering of murine teeth. J Dent Res 2004; 83: $518-22$.

196Chai Y, Slavkin HC. Prospects for tooth regeneration in the $21^{\text {st }}$ century: a perspective. Microsc Res Tech 2003; 60:469-79. 